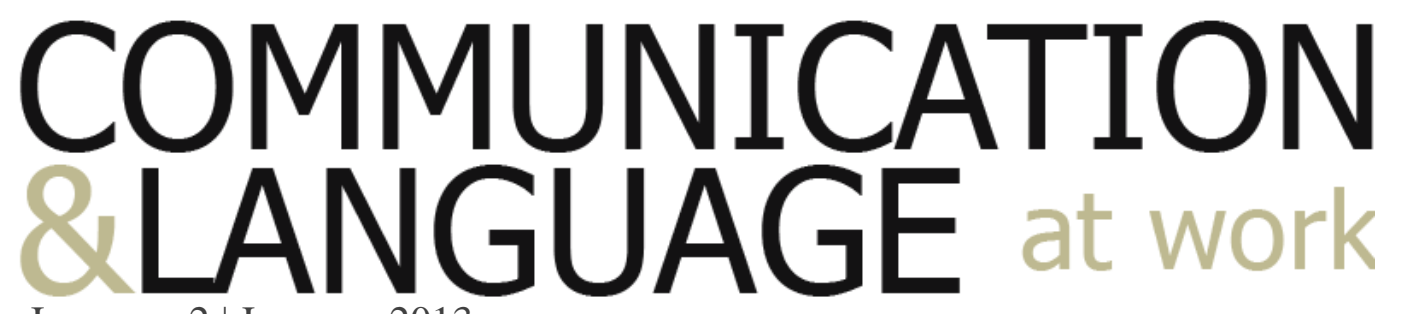

Issue no. 2 | January, 2013

Technical Communication

\title{
Communication Design
}

Kerstin Fischer \& Helena Larsen

(pp. 26-32)

http://ojs.statsbiblioteket.dk/index.php/claw/article/view/7889

Subscribe:

$\underline{\text { http://ojs.statsbiblioteket.dk/index.php/claw/notification/subscribeMailList }}$

Archives:

http://ojs.statsbiblioteket.dk/index.php/claw/issue/archive

\section{Publishing:}

http://ojs.statsbiblioteket.dk/index.php/claw/about/submissions\#onlineSubmissions

\section{Contact:}

http://ojs.statsbiblioteket.dk/index.php/claw/about/contact

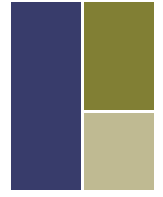

| Bridging Theory and Practice |

http://ojs.statsbiblioteket.dk/index.php/claw 


\title{
Communication Design
}

\author{
Kerstin Fischer \\ Associate Professor \\ University of Southern Denmark \\ Helena Larsen \\ Ph.D \\ University of Southern Denmark
}

\begin{abstract}
In this article, we present our approach to communication design, which focuses on the organization of information for a particular audience and communicative purpose, drawing on knowledge from a range of disciplines including linguistics and communication. We argue that communication design can help companies save enormous costs and attract, as well as keep, customers. We present an example for a redesign by one of the students from our study programs at SDU Sonderborg that illustrates the kind of work communication designers can do.
\end{abstract}

\section{Why communication design?}

Everyone knows that they need a graphic designer to make a document look appealing or even beautiful, and probably most companies will hire a web designer to take care of the technical aspects of their websites. In contrast, the organization of content, as well as its presentation and wording, in the creation of texts, tables, forms, brochures and even websites often lies in the hands of those who are experts on content, not in the hands of communication experts. Designing such documents from a communication perspective can however increase their effectiveness considerably. In particular, it is hardly known that communication design can contribute to attracting and keeping customers, saving costs in company internal communication, making communication more effective, useful, pleasant etc. and thus saving time, money and trouble.

\section{Some numbers and facts}

There are some studies that show how much money can be saved when companies employ communication designers to revise their internal communication, such as forms, templates for memos and interfaces for information storage and retrieval. For instance, Motorola saved \$20,000,000/year after revising their data entry forms (Therrien 1991). Similarly, forms for educational grants by the Dutch Department of Education and Science created so many difficulties for form-filers that each year an average of 60,000 
forms had to be returned. A revision saved enormous clerical costs, postage, and handling (Jansen \& Steeholder 1992).

Another domain in which communication design has measurably contributed to companies' success is branding. Branding aims at creating strong relationships between a company and its customers, by making them feel good about the company and thus preventing them from switching to another, possibly cheaper, provider. This is particularly relevant for companies whose products do not have special characteristics for customers, such as electricity or telephone services (Delin et al. 2006). Communication designers do not only choose and organize content in ways that support strong relationships with customers, but they also make subtle choices in language that foster a company's positive image in such mundane documents as telephone bills.

Furthermore, communication design can contribute considerably to increasing the usability of documents by ensuring that readers are confronted with the right amounts of information in the right order at the right time. Especially with respect to technology interaction, it is crucial that customers experience the interaction as easy and efficient since they are likely to either blame themselves for failures (which is still bad for the company because then they won't buy any technological products any more, cf. Schriver 1997) or understand unsmooth interaction, for instance, with a company's website, as unsmooth interaction with the company as a whole-leading them to choosing another company next time (Krug 2005).

Finally, information needs to be presented appropriately for a particular audience; investigations into the challenger disaster, for example, showed that the researchers at NASA had in fact presented their managers with the crucial information about the vulnerable tiles of the rocket long before the crash, yet they had not succeeded in communicating this information understandably to the relevant decision makers (Tufte 2005).

These examples indicate that communication design can contribute considerably to a company's success on the market.

\section{So what is communication design?}

The communication design process begins long before the graphic design. Since the conveying of information is at the heart of the communication endeavor, the starting point of the design process must be considering what the message is intended to be: Which ideas and concepts are relevant? How is the content structured? What are potential readers' information needs? Figure 1 illustrates some of the most important considerations in the communication design process - from collecting and structuring the information to be presented, via the consideration of the particular audience's needs 


\section{C ommunication \& Language at Work}

to the selection and framing of the information presented in appropriate forms and the genre-specific realizations of the chosen contents with respect to a particular artifact.

The first step in the design process is to understand the content and to gather information - a lot of information. Just like a good teacher, the communication designer needs to know much more of the topic than is actually going to be included in the final product.

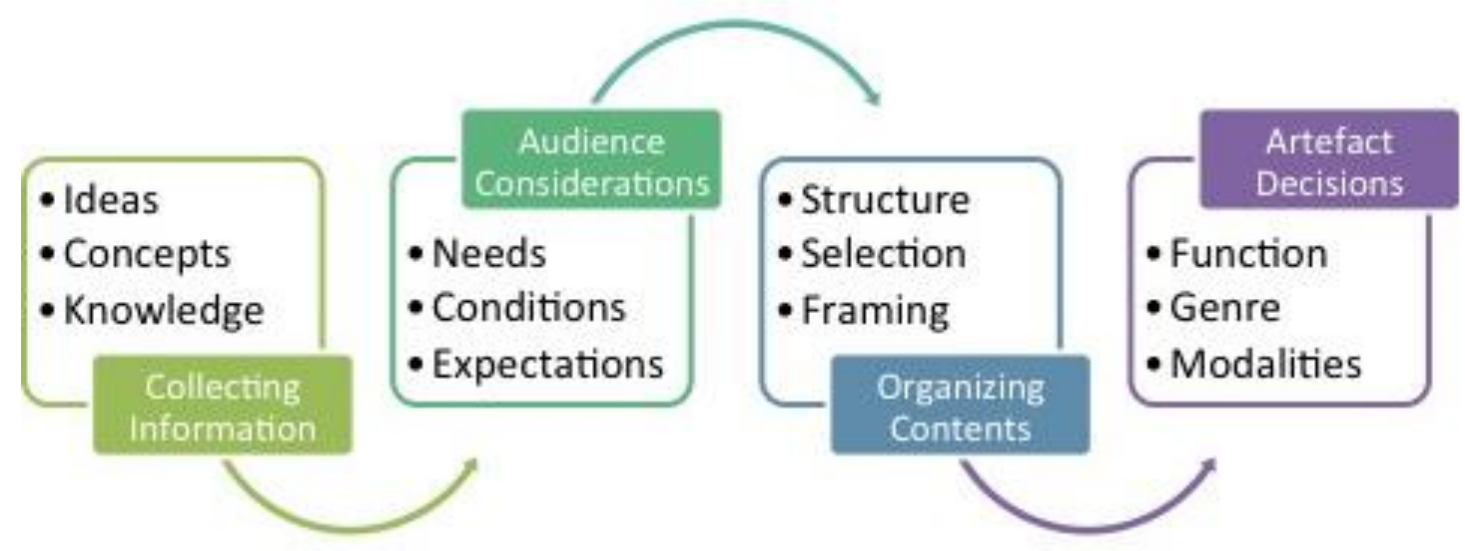

Figure 1: The Communication Design Process

The next step in the design process is the task of structuring and organizing the content in terms of what is needed for the current communicative purpose. Here the designer considers the audience, its needs, conditions and expectations as well as possible questions and reactions. This part of the communication design process is of great importance; knowing your audience is the only way to make informed decisions on the selection and framing of contents as well as on the appropriate genre and type of artifact for the publication of the information. Part of this process is also a question of which kinds of information are best presented as text, which as images and which as graphs and how these different kinds of information interact (e.g. Jensen 2012). The communication designer will also consider at which places in the presentation of the information the content needs to be supported by means of examples, data or additional arguments, which should be included for the document to fulfill its purposes. Moreover, the communication designer will consider people's expectations with respect to the particular artifact created and choose the particular wording and rhetorical structure for the information presented according to their communicative function. Only when the communication designer has worked through these stages of the communication design process do we have a solid enough basis to start constructing the end product in terms of layout and typography. 


\section{Communication Design in Sønderborg}

The master program in communication design ${ }^{1}$ at SDU Sønderborg combines courses in various areas of communication design (document design, knowledge management and terminology, empirical methods for user studies, and interaction with technology) with thorough language knowledge of a second language, in particular, Danish, German or English. Many students furthermore combine their Master in Communication Design with courses in Product Design ${ }^{2}$ offered by the Mads Clausen Institute in Sønderborg. Thus, our students learn to structure information, make relevant selections for a particular audience, communicative purpose and artifact (such as a brochure, a flyer, a form or a web site), and to put these ideas into appropriate linguistic and graphical forms.

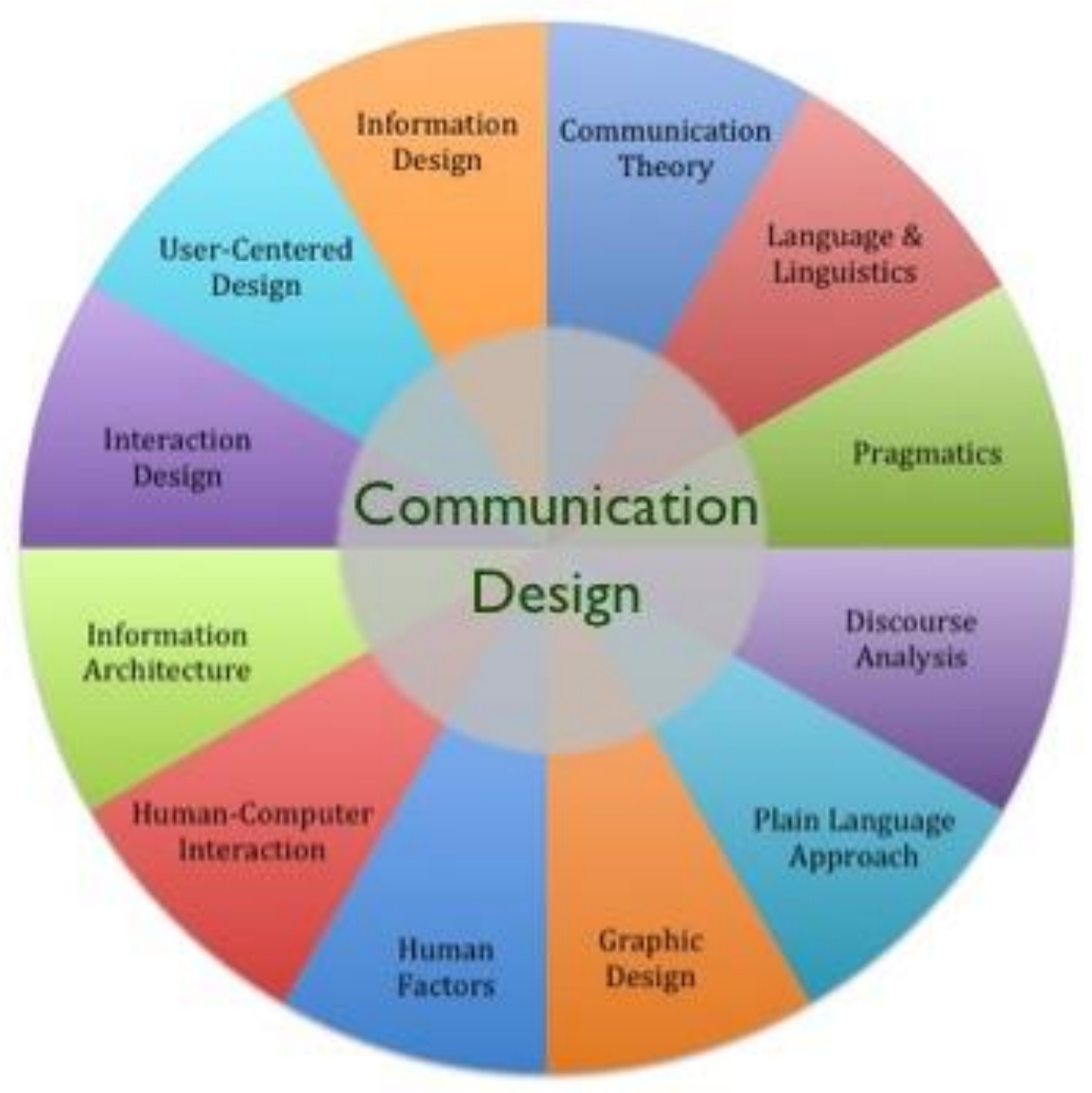

Figure 2: Resources for Communication Design

Figure 2 indicates the different disciplines that feed into communication design, illustrating the interdisciplinary nature of the field. On the one hand, different

\footnotetext{
${ }^{1}$ http://www.sdu.dk/en/Uddannelse/Kandidat/cand_ling_merc_i_kommunikationsdesign

${ }^{2}$ http://www.sdu.dk/Uddannelse/kandidat/it_produktudvikling
} 
perspectives on language and communication play an important role, on the other, disciplines with roots in design and user studies contribute to communication design.

Figures 3 and 4 present an example study carried out by one of our students, Rebekka Schlippe. Figure 3 shows a table that she took as a starting point for re-design; Figure 4 is the result of her redesign. In particular, she re-organized the information on the basis of the audience's information needs, clustering different types of methods for contraception and marking both the most and the least safe methods in green and red respectively. She also added information, namely how often the method needs to be applied. Only then she attended to a more pleasant and readable design. Thus, in order to fulfill its communicative purpose, a document has to be designed by starting from the conscious choice of the contents to be presented for a particular intended audience.

\begin{tabular}{|c|c|c|}
\hline & Typical use & Correct use \\
\hline \multicolumn{3}{|l|}{ Cervical cap } \\
\hline Previous births & 32 & 26 \\
\hline No previous birth & 16 & 9 \\
\hline \multicolumn{3}{|c|}{ Condom (without spermicide) } \\
\hline Male & 15 & 2 \\
\hline Female & 21 & 5 \\
\hline $\begin{array}{l}\text { Diaphragm with } \\
\text { spermacide }\end{array}$ & 16 & 6 \\
\hline \multicolumn{3}{|l|}{ Sponge } \\
\hline Previous births & 32 & 20 \\
\hline No previous births & 16 & 9 \\
\hline \multicolumn{3}{|l|}{ Fertility awareness } \\
\hline Ovulation & 23 & 3 \\
\hline Symptothermal & $13-20$ & 2 \\
\hline TwoDay & 14 & 4 \\
\hline Standard days & 12 & 5 \\
\hline Lactational amenorrhea* & 5 & $<2$ \\
\hline Withdrawal & 27 & 4 \\
\hline Depot-provera & 3 & $<1$ \\
\hline \multicolumn{3}{|l|}{ IUD } \\
\hline Copper T or Mirena & |<1 & $\mid<1$ \\
\hline Patch & 8 & $<1$ \\
\hline \multicolumn{3}{|l|}{ OCPs } \\
\hline $\begin{array}{l}\text { Progestin only or combination } \\
\text { estrogen-progestin }\end{array}$ & 8 & $\mid<1$ \\
\hline Ring & 8 & $<1$ \\
\hline Female sterilization & $<1$ & $<1$ \\
\hline Vasectomy & $<1$ & $<1$ \\
\hline \multicolumn{3}{|l|}{ Emergency contraception } \\
\hline Pills & \multicolumn{2}{|c|}{$\begin{array}{l}\text { Pregnancy rate decreased by } 75 \text { to } 89 \text { percent, depending on the regimen used (higher pregnancy rate is for combined estrogen-progestin } \\
\text { pills, lower pregnancy rate is for levonorgetrel alone) }\end{array}$} \\
\hline IUD & \multicolumn{2}{|l|}{ Pregnancy rate decreased by 99 percent } \\
\hline Implanon & $<1$ & k 1 \\
\hline Spermicides & 29 & 18 \\
\hline No method & 85 & 85 \\
\hline
\end{tabular}

Data refer to number of oreonancies Der 100 women durino first vear of use

Fig 3: Original table illustrating different methods for contraception that was then re-designed by our student (see Figure 4$)^{3}$

\footnotetext{
${ }^{3}$ The table (http://www.contraceptivetechnology.org/CTFailureTable.pdf) has been revised in the meantime and is based on Trussell J. Contraceptive Efficacy. In Hatcher RA, Trussell J, Nelson AL, Cates W, Kowal D, Policar M. Contraceptive Technology: Twentieth Revised Edition. New York NY: Ardent Media, 2011.
} 


\section{Efficiency of contraception methods}

(Measured according to failure rate in the first year of use in percent)

\begin{tabular}{|c|c|c|c|}
\hline Contraception Type & $\begin{array}{l}\text { Typical } \\
\text { use }\end{array}$ & $\begin{array}{l}\text { Perfect } \\
\text { use }\end{array}$ & $\begin{array}{l}\text { Frequency } \\
\text { of use }\end{array}$ \\
\hline \multicolumn{4}{|l|}{ Hormone-based contraception } \\
\hline $\begin{array}{l}\text { Contraceptive Injection } \\
\text { (Depo-Provera: progestin-only) }\end{array}$ & $3 \%$ & $0.3 \%$ & every 3 months \\
\hline $\begin{array}{l}\text { Implanon } \\
\text { (progestin-only implant; inserted in arm) }\end{array}$ & $0.05 \%$ & $0.05 \%$ & every 3 years \\
\hline $\begin{array}{l}\text { Oral Contraceptive Pills } \\
\text { (progestin only or estrogen-progestin) }\end{array}$ & $8 \%$ & $0.3 \%$ & Daily \\
\hline $\begin{array}{l}\text { Patch } \\
\text { (progestin-estrogen transdermal patch) }\end{array}$ & $8 \%$ & $0.3 \%$ & every 3 weeks \\
\hline $\begin{array}{l}\text { Ring } \\
\text { (NuvaRing: progestin-estrogen vaginal ring) }\end{array}$ & $8 \%$ & $0.3 \%$ & every 3 weeks \\
\hline \multicolumn{4}{|l|}{ Natural Birth Control } \\
\hline $\begin{array}{l}\text { Knaus-Ogino Method (Rhythm Method) } \\
\text { (based on calculating days of cycle) }\end{array}$ & $25 \%$ & $9 \%$ & Daily \\
\hline $\begin{array}{l}\text { Lactational amenorrhea method (LAM) } \\
\text { (based on natural after birth infertility) }\end{array}$ & $5 \%$ & $0.5 \%$ & every few hours \\
\hline $\begin{array}{l}\text { Ovulation/cervical mucus Method } \\
\text { (based on regular checks of the cervical mucus) }\end{array}$ & $23 \%$ & $3 \%$ & Daily \\
\hline $\begin{array}{l}\text { Standard Days Method } \\
\text { (based on counting the days of the cycle) }\end{array}$ & $12 \%$ & $5 \%$ & Daily \\
\hline $\begin{array}{l}\text { Sympto-Thermal Method } \\
\text { (based on determining the basal body-temperature) }\end{array}$ & $13-20 \%$ & $2 \%$ & Daily \\
\hline $\begin{array}{l}\text { TwoDay Method } \\
\text { (based on monitoring of secretions) }\end{array}$ & $14 \%$ & $4 \%$ & Daily \\
\hline \multicolumn{4}{|l|}{ Barrier Contraception } \\
\hline $\begin{array}{l}\text { Cervical Cap } \\
\quad \text { previous births } \\
\text { - no previous births } \\
\text { placed over cervix to block sperm from entering uterus }\end{array}$ & $\begin{array}{l}32 \% \\
16 \%\end{array}$ & $\begin{array}{l}26 \% \\
9 \%\end{array}$ & $\begin{array}{l}\text { before } \\
\text { intercourse }\end{array}$ \\
\hline Condom (Male) & $15 \%$ & $2 \%$ & \multirow{2}{*}{$\begin{array}{l}\text { before } \\
\text { intercourse }\end{array}$} \\
\hline Condom (Female) & $21 \%$ & $5 \%$ & \\
\hline $\begin{array}{l}\text { Diaphragm } \\
\text { latex/silicone dome seals against the walls of vagina }\end{array}$ & $16 \%$ & $6 \%$ & $\begin{array}{l}\text { before } \\
\text { intercourse }\end{array}$ \\
\hline $\begin{array}{l}\text { Sponge } \\
\quad \text { previous births } \\
\cdot \text { no previous births } \\
\text { combination of barrier \& spermicidal method }\end{array}$ & $\begin{array}{l}32 \% \\
16 \%\end{array}$ & $\begin{array}{l}20 \% \\
9 \%\end{array}$ & $\begin{array}{l}\text { before } \\
\text { intercouse }\end{array}$ \\
\hline \multicolumn{4}{|l|}{ Alternative Methods } \\
\hline $\begin{array}{l}\text { Essure (Female sterilization) } \\
\text { micro-inserts cause tissue growth \& blockage in fallopian } \\
\text { tubes }\end{array}$ & $0.2 \%$ & $0.2 \%$ & once \\
\hline $\begin{array}{l}\text { Intra Uterine Device (IUD) } \\
\text { small object placed in uterus }\end{array}$ & $0.8 \%$ & $0.6 \%$ & $5-12+$ years \\
\hline $\begin{array}{l}\text { Vasectomy (Male sterilization) } \\
\text { vasa deferntia are cut and sealed surgically }\end{array}$ & $0.15 \%$ & $0.1 \%$ & once \\
\hline $\begin{array}{l}\text { Tubal ligation (Female sterilization) } \\
\text { fallopian tubes are cut and sealed surgically }\end{array}$ & $0.5 \%$ & $0.5 \%$ & once \\
\hline $\begin{array}{l}\text { Spermicides } \\
\text { chemical substance can be used alone or in combination }\end{array}$ & $29 \%$ & $18 \%$ & $\begin{array}{l}\text { before } \\
\text { intercourse }\end{array}$ \\
\hline
\end{tabular}

Figure 4: Redesigned table (by our student Rebekka Schlippe) 
C ommunication \& Language at Work

\section{Conclusion}

To sum up the above discussion, communication design can support businesses and institutions in various, underestimated and hitherto often neglected ways. However, in the same way in which communication is essential to a person's standing in the world, it is crucial to a company's success, and thus it should not come as a surprise that designing a company's internal and external communications to be most effective can pay off in various ways.

\section{References}

Delin, Judy, Searle-Jones, Abi and Waller, Rob (2006): Branding and Relationship Communications. In Carliner, S., Verkens, J. P. \& de Waele, C.A.E. (eds.) Information and document design: Variety on the research. Amsterdam: John Benjamins.

Jansen, C.J.M. \& Steeholder, M. (1992): Forms as a source of communication problems. Journal of Technical Writing and Communication 22: 179-194.

Jensen, Lars Christian (2012): The Effectiveness of Screen Capture in Instructions. Danish HCI Research Symposium DHRS '12, Sonderborg.

Krug, Steve (2005): Don't Make me Think! A Common Sense Approach to Web Usability. $2^{\text {nd }}$ edition. New Riders.

Schriver, Karen (1997): Dynamics in Document Design. Wiley.

Therrien, Lois (1991): Motorola and NEC going for glory. Business Week, pp. 60-61.

Tufte, Edward (2006): The Cognitive Style of Power Point: Pitching out corrupts within. Graphics Press. 